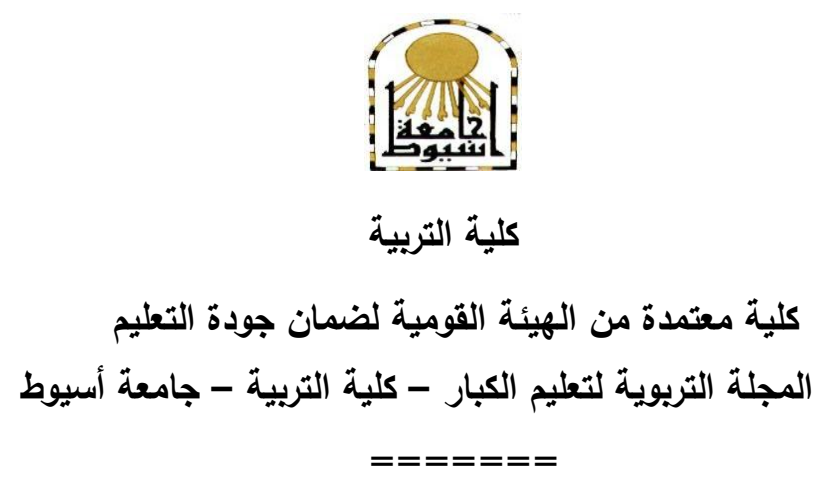

Improving 2nd year prep stage pupils' predicting and summarizing skills through short stories

By

Eman Muhammed Muhammed Ahmed

Supervised by

Prof.Dr.Mohamed Abd Alwahid Ali Dr. Ahmed M. Abdul- Rahman

Professor of curriculum

Lecturer of curriculum

$\&$ instruction, Faculty of

Education, New Valley University

$\&$ instruction, Faculty of

Education, Assiut University

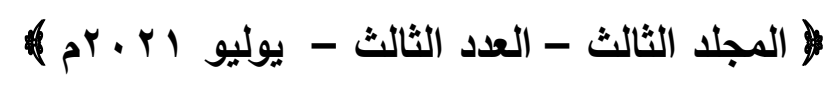

Adult_EducationAUN@aun.edu.eg 


\section{Improving 2nd year prep stage pupils' predicting and summarizing skills through short stories}

\section{Prof.Dr.Mohamed Abd Alwahid Ali Dr. Ahmed M. Abdul- Rahman}

Eman Muhammed Muhammed Ahmed

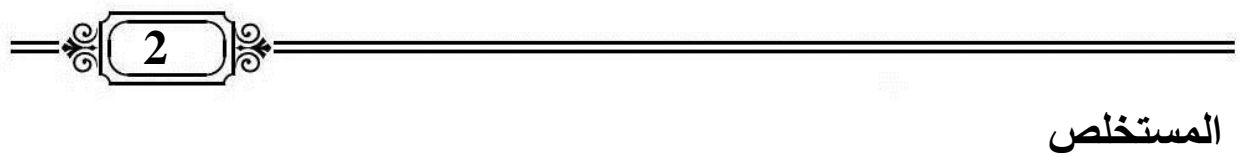

هدفت هذه الدراسة إلى قياس فاعلية استخدام القصص القصير في تنمية مهارتي التنبؤ

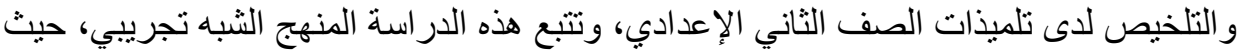
تكونت عينة الدراسة من (•ج) طالبة من طالبات الصف الثاني الإعدادي بمدرسة الوليدية

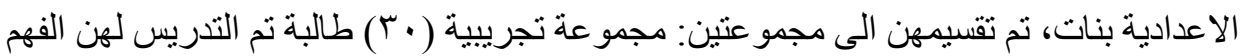

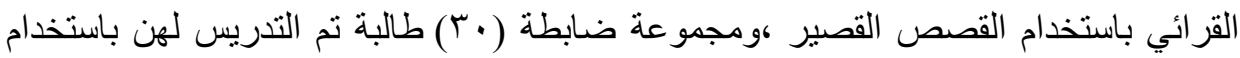

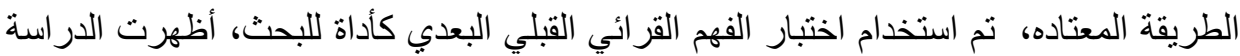
فاعلية استخدام القصص القصير في تنمية مهارتي التنبؤ و التلخيص لدى تلميذات الصف التفي الثاني الاعدادي، لصالح المجموعة التجريبية. الكلمات المفتاحية: الفهم القر ائي، التنبؤ بالأحداث، تلخيص القصة 


$$
\text { المجلة التريوية لتعليم الكبار - كلية التربية - جامعة أسيوط }
$$

\section{3}

\section{Abstract}

The aim of the present study was to investigate the effectiveness of using short stories in developing predicting and summarizing skills for $2^{\text {nd }}$ year prep school pupils. The study followed the quasi-experimental design. The participants of the study were 60 female pupils from Elweleda prep school for girls. They were divided into two groups: the experimental group (30) were taught reading comprehension by using short stories, and the control group (30) were taught reading comprehension by using the regular method. The instrument of the present study was a pre-post reading comprehension test. The study showed the effectiveness of using short stories in developing predicting and summarizing skills among $2^{\text {nd }}$ year prep stage pupils, in favor of the experimental group.

Key words : Reading comprehension, Predicting events, Summarizing stories 


\section{Improving 2nd year prep stage pupils' predicting and}

summarizing skills through short stories

\section{Prof.Dr.Mohamed Abd Alwahid Ali Dr. Ahmed M. Abdul- Rahman Eman Muhammed Muhammed Ahmed}

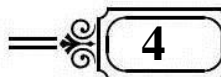

\section{Introduction}

Reading is one of the four skills in learning English besides listening, speaking and writing. Students can increase their information, knowledge and experience through reading. Reading is essential to the success of language learning in general, and learning a foreign language in particular. It improves learners' vocabulary, writing and speaking skills.

Reading is an important activity as it enables readers to find information from a variety of texts, to get pleasure, to get jobs, and to deal with some study purposes. Harmer (2007) supports this by saying that reading is beneficial not only for careers, study, and pleasure, but also for language acquisition. Reading comprehension process means being able to understand and build a meaning from a text. To understand the text accurately, the students need to connect between what they read and what they already know. It can be understood that the ability to comprehend content in a text is the main goal of reading in the learning process. Richard and Renandya (2002: 227) also state that reading for comprehension is the main purpose for reading.

As reading is a complex process, Grabe \& Stoller (2004) state that many researchers try to explain the fluent reading process by analyzing the process into a set of sub skills. Those sub skills include finding the topic sentence, supporting ideas, antonym, synonym, reference and inference. Successful reading is determined by the comprehension of the reader in the reading process. To achieve these purposes, there are some strategies that can be applied by the students in reading, such as highlighting, summarizing, note- taking, paraphrasing, etc. 


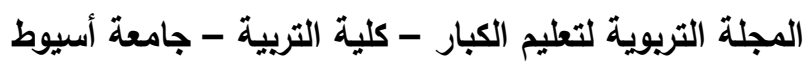

\section{5}

Rajab and Al-Sadi (2015) identified certain habits and preferences of EFL learners regarding various personal practices of the reading process in the first language (L1) as well as in second language (L2). The students' responses indicated their lack of interest as well as the lack of motivation towards 'academic reading' in both L1 and L2. As the students' problems in understanding the reading text are realized, a variety of reading strategies has been introduced to EFL classes to develop their reading skill. Predicting, making connections, inferring, questioning and summarizing are metacognitive reading comprehension strategies.

Oczkus (2003:13) states that good readers have a purpose for reading and predicting is a strategy for improving comprehension and helps the readers set a purpose for their reading. Duke and Pearson (2005) clarify that without this aspect of the prediction process, it becomes meaningless to improve the student's comprehension. Students can make connections based upon how characters in a story relate to each other, or how story elements relate between stories or by comparing characters in a story to characters of today.

As stated by Adler (2001:5), visualization requires the reader to construct an image of what is read. This image is stored in the reader's memory as a representation of the reader's interpretation of the text (National Reading Panel, 2000). Inferring, as clarified by Serafini (2004:95), refers to reading between the lines. Students need to use their own knowledge along with information from the text to draw their own conclusions. Questioning is a process readers use before, during, and after reading. Harvey and Goudvis (2000:6) state that the questioning process requires readers to ask questions of themselves to construct meaning, enhance understanding, find answers, solve problems, find information, and discover new information. Adler (2001) states that the process of summarization requires the reader to determine what is important when reading and to condense the information in the reader's own words. 


\section{Improving 2nd year prep stage pupils' predicting and summarizing skills through short stories \\ Prof.Dr.Mohamed Abd Alwahid Ali Dr. Ahmed M. Abdul- Rahman Eman Muhammed Muhammed Ahmed}

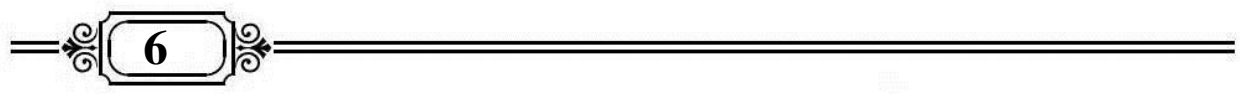

Nuttall (2000:38) claims that conscious development of reading skills is important because teachers are trying to equip students for the future, and so it is impossible to familiarize students with every text they will ever want to read; but what teachers can do is give them techniques for approaching texts of various kinds, to be used for various purposes, that is the essence of teaching reading.

Nilsson (2003:4) states that psychological and psycholinguistics research strongly indicate that the quality of reading as psychological processing of the target language input depends on whether the reader finds the text personally significant. That is, if the text relates to the reader's background knowledge and experiences, interests and information needed.

Literature has revealed that the reader's awareness and observation of the processes of understanding is an important aspect of the skilled reader. (Alexander \& Jetton 2000; Makhtari \& Reichard 2002) also noted that these processes of awareness and observation are often referred to in the literature as being super cognitive, which can be considered the extent of knowledge of the reader to read and restraint mechanisms exercised during reading the text.

Therefore, reading comprehension is the real essence of reading. Teaching reading in all stages aims at improving the ability to comprehend the contents of the printed text. Real reading is the reading that is associated with understanding, and if reading is a complex process consisting of several sub-processes, Understanding is one of the most important processes around which other processes are based. 


\section{المجلة التربوية لتعليم الكبار - كلية التربية - جامعة أسيوط}

\section{7}

Harmer (2002:39) noted that teaching reading starts from primary school to university using different strategies. The strategy used should involve students in the reading process. This means that the students will experience the real learning process and how to understand any text they may read. Farrell (2001) is among those who support the use of other modern strategies to improve sub-reading skills in students.

The unwillingness in reading and the need to achieve success in English among prep school pupils create a problem. The teacher wants to improve their English, but they are not really willing to read English. They read English materials lazily in the class. They said the materials or the topics are not interesting to read. They are bored of the monotonous topics. For this reason, finding the right media can help pupils to solve their problems in reading comprehension. The researcher introduced a new way to encourage the reading willingness in the pupils through using short stories.

The researcher used short stories because in teenagers' level, short stories are the most interesting literary work to read. The short story is not too long to read and has various interesting topics. Short stories are a one of media that can make it easier for the pupils to remember what they have read and help them read more carefully. Usually, a short story will focus on only one incident, has a single plot, a single setting, a limited number of characters, and covers a short period of time. Pathan (2013) stated that short stories are strongly recommended, which are one of the best methods, for effective teaching of foreign language skills. Furthermore, Erkaya (2005) said that short stories motivate students to continue reading so 


\section{Improving 2nd year prep stage pupils' predicting and}

summarizing skills through short stories

\section{Prof.Dr.Mohamed Abd Alwahid Ali Dr. Ahmed M. Abdul- Rahman Eman Muhammed Muhammed Ahmed}

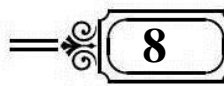

that they can solve the problem. So hopefully by using this way, they can improve their comprehension in reading without boredom. Pardede (2011) also mentioned that the use of short stories is more interesting to use as a part of language skills classes, and as a material for enjoyment. According to Sage (1987 as cited in Hismanoglu, 2005) using short stories is a useful technique in language classes as short stories are short; it makes it easy for both the teacher and the students to cover it.

Being aware of the importance of reading comprehension for the 2nd stage pupils, the teacher can use short stories to improve the pupils' reading comprehension. Therefore, a quasi-experimental study entitled 'Improving 2nd year prep stage pupils' predicting and summarizing through short stories" is conducted.

\section{Studies related to short stories}

Abu Zahra and Farrah (2016) carried out a study about using short stories in the EFL classroom which examined students' attitudes towards using short stories in the EFL classroom. In order to achieve this aim, the researchers used a questionnaire to examine students' attitudes towards using short stories. The participants of this study included 2nd to 4th year students majoring in English in the fall semester of the academic year 2014-2015 at Hebron University. The result of the study proved that the students held positive attitudes towards using short stories in the EFL learners due to the Grade Point Average (GPA). 


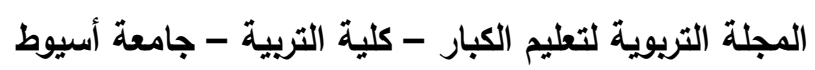

9

Firmasary (2015) conducted a study aiming to use short stories to improve students' reading comprehension of the Second Year Students Of SMPN 2 Kota Bengkulu. The researcher used the quasi - experimental design. The participants of this study were 80 second year high school students from 2nd year high school. It was found that short stories can improve students' reading comprehension. Short story made students interested and encouraged their willingness to read the text of English.

Pourkalhor and Kohan (2013) carried out a study about teaching reading comprehension through short stories in advanced classes. The study was applied on 40 advanced-level tenth grade students. The participants of the study were divided into two groups; the experimental group (20) students who were taught by using the book Modern Short Stories in English by Robert J. Dixon. The control group (20) students they taught by material from different reading books. Data was gathered using a reading comprehension test. However, the findings proved that the students who were taught by using short stories did much better than the students who were taught by using the traditional way.

Sari (2013) conducted a study that aimed at using short stories to develop students' reading comprehension skills. To measure this, the researchers used a test and a questionnaire. The participants of the study consisted of a group of 40 students, who were classified in two groups, the control group which was taught by using instructional-based textbook, and the experimental group which was taught by using short stories as a reading comprehension test. The result was analyzed by using T-test, which found that the group which was taught by using short stories did better than the other. 


\section{Improving 2nd year prep stage pupils' predicting and}

summarizing skills through short stories

\section{Prof.Dr.Mohamed Abd Alwahid Ali Dr. Ahmed M. Abdul- Rahman Eman Muhammed Muhammed Ahmed}

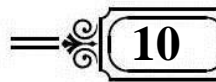

Zeraatkar and Hadipanah (2013) studied the effects of short stories on Junior High school EFL Learners' Reading Skills in Birjand. To achieve this objective, the researchers chose 40 students aged 40 randomly from Birjand's teacher training center, and they were divided in two groups, which were the control group that was taught by using the traditional way, and the experimental group that was taught by using short stories, and the data were collected by a pretest and a post test for the two groups. The results showed that using short stories in teaching will produce positive outcomes on reading, motivates students, and making the teaching more interesting.

Rabba (2012) did a study about teaching short stories for 10th grade in classrooms in Palestine. The researchers conducted this study on 48 tenth grade students at $\mathrm{Al}$ Thahrieh School for Boys. In order to achieve the study goal, the researchers collected data by a questionnaire, assessment sheet, and pre and post test. The sample of the study was divided into groups, the experimental group and the controlled group. After statistical treatment, the researchers came up with a result that students became more active by using short stories.

\section{Context of the study}

Based on the researcher's observation, it was found that the pupils had poor reading comprehension skills. They also had problems finding the main idea and specific information the author wanted to convey to the reader and the pupils could not predict what the text was about. With regard to the initial observation, it was found that the unsatisfactory results of pupils' understanding of the reading text resulted from several factors. 


$$
\text { المجلة التربوية لتعليم الكبار - كلية التربية - جامعة أسبوط }
$$

\section{1}

First, most pupils did not know many of the meanings of the words in the text. Second, they could not understand the content of the text, which made it difficult for them to understand important information such as the main idea, the details mentioned and not mentioned, and references. Third, they were unable to learn how to do the reading process, as they were not trained in how to use reading strategies to understand the text effectively. Fourth, teachers still use traditional teaching methods, briefly explaining the text and asking students to answer questions about the text. Finally, students did not feel motivated to do so.

To confirm the poor reading comprehension skills of the pupils, the researcher conducted a preliminary reading comprehension test on a group of (30) preparatory school pupils.

\section{The results were as follows:}

\begin{tabular}{|c|c|}
\hline Sub-skills of reading comprehension & $\begin{array}{c}\text { percentage of weakness among female } \\
\text { pupils }\end{array}$ \\
\hline \hline Predicting story events & $70 \%$ \\
\hline Summarizing stories & $57 \%$ \\
\hline
\end{tabular}

All these problems hinder the improvement and progress of language learning. Therefore, this study attempts to investigate the effectiveness of using short stories in improving predicting and summarizing of $2^{\text {nd }}$ year prep stage pupils. Many researchers recommended using short stories as Abu Zahra and Farrah (2016), Firmasary (2015), Zeraatkar and Hadipanah (2013), and Rabba (2012)

\section{Statement of the problem}

The $2^{\text {nd }}$ year prep school pupils of El-Weledya for girls had some weaknesses in predicting the events and summarizing skills. To overcome these problems, the researcher attempted to conduct a quasiexperimental study with the use of short stories in order to improve the pupils' predicting and summarizing skills. 


\section{Improving 2nd year prep stage pupils' predicting and}

summarizing skills through short stories

\section{Prof.Dr.Mohamed Abd Alwahid Ali Dr. Ahmed M. Abdul- Rahman Eman Muhammed Muhammed Ahmed}

\section{$=\sqrt[4]{6}$}

\section{Definitions of terms}

\section{Predicting events}

Duffy (2009: 102) states that "Predicting is not a wild guess, but a thoughtful hypothesis based on clues." In this study it means activating the prior knowledge of the $2^{\text {nd }}$ year prep stage school pupils of El Weledya about a topic by combining what they know with the new material in the text. Predicting is based on clues in the text such as pictures, titles, and sometimes lines from the text.

\section{Summarizing stories}

Wormeli (2005: 2) states that "summarizing can be thought of as complex processes where students spend time restating the essence of text or an experience in as few words as possible or in a new, yet efficient, manner". In this study it means the ability of $2^{\text {nd }}$ year pupils to get the central idea from a large chunk of information and condense it to a brief statement.

\section{A Short story}

Cambridge Advanced Learners' Dictionary (2003:1162) defines 'short story' as "an invented story which is no more than about 10,000 words in length". In this study, it is defined as a simple and short literary text which is easy to be read by the pupils in a short time. It can motivate pupils to read, because it is interesting, enjoyable and funny for them.

\section{Aims of the study}

This study aims at improving 2nd year prep stage pupils' predicting story events and summarizing the story through short stories. 


$$
\text { المجلة التربوية لتعليم الكبار - كلية التربية - جامعة أسيوط }
$$

\section{3}

\section{Question of the study}

The problem of the study can be stated in the following major question:

- What is the effectiveness of using short stories in improving predicting events and summarizing the story of $2^{\text {nd }}$ year prep stage pupils?

\section{Hypotheses of the study}

To answer this question, the researcher proposed the following hypotheses:

1. There would be no statistically significant difference between the mean scores of the control and experimental group on the preadministration of the reading comprehension test.

2. There would be a statistically significant difference between the mean scores of the control and experimental group on the postadministration of the reading comprehension test, favoring the experimental group.

3. There would be a statistically significant difference between the mean scores of the experimental group on the pre-post administration of the reading comprehension test, favoring the postadministration.

\section{Delimitations of the study}

\section{The study is delimited to :}

1. A group of (60) second year preparatory stage pupils at El Weledya prep school for girls school, Assiut Governorate.

2. Some reading comprehension skills (predicting events, and summarizing the story). 


\section{Improving 2nd year prep stage pupils' predicting and summarizing skills through short stories}

\section{Prof.Dr.Mohamed Abd Alwahid Ali Dr. Ahmed M. Abdul- Rahman Eman Muhammed Muhammed Ahmed}

\section{$=\frac{\sqrt{6}}{14}$}

\section{Design of the study}

The following study used an experimental approach based on a quasi-experimental design with both experimental and control groups; (control group) where pupils learned within their group reading comprehension skills through the usual method, and (experimental group) in which pupils were taught reading comprehension skills through short stories.

\section{Materials and Instruments of the study}

\section{They are :}

1. A list of reading comprehension skills suitable for second year preparatory stage pupils.

2. A Teacher's Guide to help teachers use short stories to improve predicting events and summarizing stories for second year preparatory stage pupils.

3. A student's book to use short stories to improve predicting events and summarizing the story for $2^{\text {nd }}$ year preparatory stage pupils.

4. A Reading comprehension skills pre-post test for $2^{\text {nd }}$ year preparatory stage pupils.

\section{Participants}

The researcher selected 60 female pupils from among the $2^{\text {nd }}$ year prep stage pupils at El-Weledya prep school for girls school, Assiut Governorate. The researcher chose two classes; the first class of (30) pupils as an experimental group and the second of (30) pupils as a control group. Furthermore, the participants were chosen from the same school to be equivalent in the social, cultural, economic and academic level. 


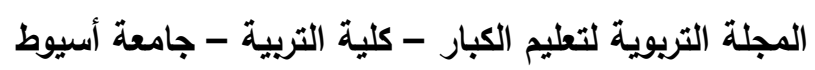

\section{5}

\section{The Procedure}

In order to investigate the significant results of reading comprehension achievement by using short stories, a group of 60 female pupils from Elweledya prep school for girls school has been sampled for the purpose of this study. The pupils were then divided into two groups the control group and the experimental group. The following procedures were followed:

\section{Pretesting}

Both experimental and control groups were given a pretest before the presentation of the material to find out the mean score of both groups before receiving the treatment. Both groups were administered an identical Pre-Test that showed the two groups had similar reading ability.

\section{The treatment}

After having the pre-test, the experimental group was taught by using short stories, while the control group received regular instruction for a period of three months. The pupils were also taught how to predict the events of the story, and summarize the story.

\section{Post testing}

After giving the treatment, the post test was given to each group. It was exactly the same as the pre-test in terms of time and the contents. It was intended to find out the mean scores of the experimental and control groups. The researcher interpreted the results and provided conclusions and recommendations of the study for further research. 


\section{Improving 2nd year prep stage pupils' predicting and}

summarizing skills through short stories

\section{Prof.Dr.Mohamed Abd Alwahid Ali Dr. Ahmed M. Abdul- Rahman Eman Muhammed Muhammed Ahmed}

\section{$=16$}

\section{Data analyses and results}

An independent t-test was used to compare the mean scores of the experimental group, and the control group on the pretest. Means and standard deviations of both groups' results on the pretest were computed. As shown in Table (1) all (t) values were statistically insignificant at 0,05 which means there was not any significant difference between the mean scores of the experimental and control groups' on the pretest of reading comprehension. Thus, it can be concluded that the two groups enjoyed the same levels of reading ability before the administration of the treatment.

Table (1): t. test independent sample results of differences between the experimental and the control group in the preadministration of the reading comprehension test.

\begin{tabular}{|c|c|c|c|c|c|c|}
\hline Skills & Group & $\mathrm{N}$ & Mean & $\begin{array}{c}\text { Std. } \\
\text { Deviation }\end{array}$ & $\mathrm{T}$ & $\operatorname{Sig}(2-$ taild $)$ \\
\hline \multirow[t]{2}{*}{ Predicting events } & Experimental & 30 & 5.36 & 1.92 & \multirow{2}{*}{0.059} & \multirow{2}{*}{ Non Sig } \\
\hline & Control & 30 & 5.33 & 1.89 & & \\
\hline \multirow{2}{*}{$\begin{array}{c}\text { Summarizing } \\
\text { the story }\end{array}$} & Experimental & 30 & 3.00 & 1.25 & \multirow{2}{*}{0.061} & \multirow[t]{2}{*}{ Non Sig } \\
\hline & Control & 30 & 3.02 & 1.23 & & \\
\hline \multirow[t]{2}{*}{ Total } & Experimental & 30 & 8.36 & 5.82 & \multirow{2}{*}{0.377} & \multirow[t]{2}{*}{ Non Sig } \\
\hline & Control & 30 & 8.53 & 5.87 & & \\
\hline
\end{tabular}

In order to test the research question that whether using short stories can enrich 2nd year prep school pupils' prediction and summarizing ability, an independent t-test was run to compare the mean scores of the two groups on the post test. As shown in Table (2) all (t) values were statistically significant at 0,05 which means there was a significant difference between the mean scores of the experimental and control groups' on the post-administration of the reading comprehension test, in favor of the experimental group. 
المجلة التربوية لتعليم الكبار - كلية التربية - جامعة أسيوط

$=17$

Table (2)

t-test Result of Differences between the Experimental and the

Control Groups in the Post-Test

\begin{tabular}{|c|c|c|c|c|c|c|}
\hline Skills & Group & $\mathrm{N}$ & Mean & Std. Deviation & $\mathrm{T}$ & $\operatorname{Sig}(2-$ taild $)$ \\
\hline \multirow{2}{*}{$\begin{array}{c}\text { Predict story } \\
\text { events }\end{array}$} & Experimental & 30 & 7.83 & 1.57 & \multirow{2}{*}{5.39} & \multirow[t]{2}{*}{0.05} \\
\hline & Control & 30 & 5.36 & 1.90 & & \\
\hline \multirow{2}{*}{$\begin{array}{c}\text { Summarize } \\
\text { the story }\end{array}$} & Experimental & 30 & 6.40 & 1.38 & \multirow{2}{*}{9.57} & \multirow[t]{2}{*}{0.05} \\
\hline & Control & 30 & 3.09 & 1.25 & & \\
\hline \multirow[t]{2}{*}{ Total } & Experimental & 30 & 14.23 & 3.71 & \multirow{2}{*}{14.09} & \multirow[t]{2}{*}{0.05} \\
\hline & Control & 30 & 8.45 & 5.91 & & \\
\hline
\end{tabular}

The previous table shows that the mean of the total score of the post-test of the experimental group reached (14.23), whereas the mean of the total score of the control group was (8.45). This result indicates that using short stories was more effective than the traditional method in developing the pupils' prediction of the story events and summarizing the story.

T-test Independent Samples was used to measure if there were statistically significant differences between the mean scores of the experimental group on the Pre-Posttest. The results are shown in table (3)

\section{Table (3)}

Differences between the mean scores of the experimental group in the pre-post application of the reading comprehension test

\begin{tabular}{|c|c|c|c|c|c|c|}
\hline Skills & Application & $\mathrm{N}$ & Mean & $\begin{array}{c}\text { Std. } \\
\text { Deviation }\end{array}$ & $\mathrm{T}$ & $\begin{array}{c}\text { Sig } \\
\text { (2- taild) }\end{array}$ \\
\hline \multirow[t]{2}{*}{ Predicting story events } & Pre & 30 & 5.36 & 1.92 & \multirow{2}{*}{13.88} & \multirow[t]{2}{*}{0.05} \\
\hline & Post & 30 & 7.83 & 1.57 & & \\
\hline \multirow[t]{2}{*}{ Summarizing the story } & Pre & 30 & 3.00 & 1.25 & \multirow{2}{*}{9.60} & \multirow[t]{2}{*}{0.05} \\
\hline & Post & 30 & 6.40 & 1.38 & & \\
\hline \multirow[t]{2}{*}{ Total } & Pre & 30 & 8.36 & 5.82 & \multirow{2}{*}{16.07} & \multirow[t]{2}{*}{0.05} \\
\hline & Post & 30 & 14.23 & 3.71 & & \\
\hline
\end{tabular}




\section{Improving 2nd year prep stage pupils' predicting and summarizing skills through short stories}

\section{Prof.Dr.Mohamed Abd Alwahid Ali Dr. Ahmed M. Abdul- Rahman}

Eman Muhammed Muhammed Ahmed

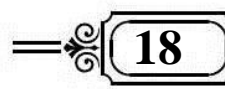

Table (3) shows that there were significant differences between the mean scores of the experimental group on the pre-test which reached (8.36), whereas the mean of the post test was (14.23) in favor of the post test, which indicates that there were some improvements in the teaching and learning process of reading as well as the pupils' predicting and summarizing skills.

Figure (1)

Comparison of the mean scores of the experimental group in the pre-post application of the reading test

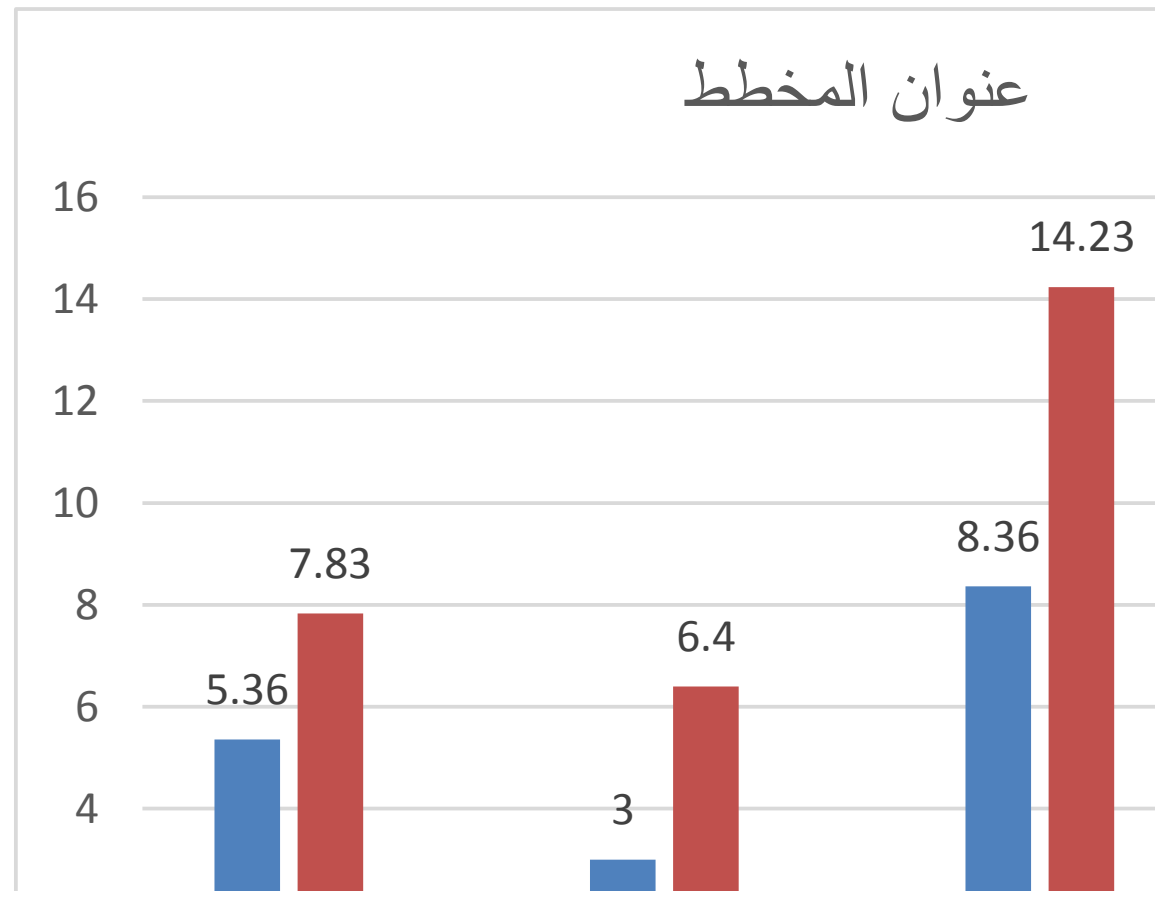




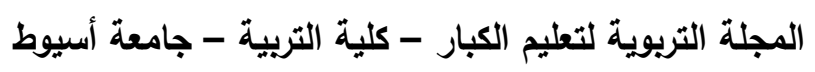

Figure ( $(1$ illustrates that the performance of the experimental group pupils in the post-application surpassed their performance in the pre-application of the same test. Pupils' scores on predicting events and summarizing the story and the total test score were in favor of the postapplication, indicating that pupils' performance in predicting and summarizing is enhanced in the post-application after studying using short stories. Therefore, the alternative hypothesis (Ha) was accepted and the null hypothesis ( $\mathrm{H} 0)$ was rejected. It indicates that there is a significant difference between the two groups. It can be concluded that the pupils in the experimental group who were taught by using short stories gained a better improvement than those in the control group who were taught by using the traditional method.

\section{Discussion of results}

In the light of the findings of this study, the results show that using short stories was highly effective in developing the pupils' levels of predicting the events and summarizing stories in the experimental group who were taught through short stories compared with the control group results who were taught according to the regular method. Using short stories increased the achievement of predicting and summarizing skills as it promotes cooperative learning. Short stories are attractive as they make students interested in reading.

This finding is supported by other researchers' findings related to teaching reading comprehension by using short stories. Lindawati (2011) found that using short stories in teaching reading comprehension was more effective compared to the traditional method. Yuliana (2013) also concluded that the use of short stories is more effective in increasing the pupils' achievement in teaching reading comprehension. 


\section{Improving 2nd year prep stage pupils' predicting and summarizing skills through short stories}

\section{Prof.Dr.Mohamed Abd Alwahid Ali Dr. Ahmed M. Abdul- Rahman Eman Muhammed Muhammed Ahmed}

\section{$=\frac{\pi}{20}$}

\section{References}

Adler, C. R. (Ed.). (2001). Put reading first: The research building blocks for teaching children to read. Jessup, MD: ED Pubs, 4756.

Alexander, P. A., \& Jetton, T. L. (2000). Learning from Text: A Multidimensional and Developmental Perspective. In M. Kamil, P. Mosenthal, P. D. Pearson, \& R. Barr (Eds.), Handbook of Reading Research (Vol. 3, pp. 285-310). Mahwah, NJ: Erlbaum.

Davis, A. (2011). Building Comprehension Strategies: for the primary years (p. 158). South Yarra, Vic.: Eleanor Curtain Publishing.

Duffy, G. G. (2009). Explaining Reading: A Resource for Teaching Concept, Skills, and Strategies 2nd Ed. United States of America: The Guildford Press.

Duke, N. K., \& Pearson, P. D. (2009). Effective practices for developing reading comprehension. Journal of education, 189(1-2), 107-122.

El Farra, M. A., \& Abu Zahra, N. A. (2016). Using Short Stories in the EFL Classroom. IUG Journal of Humanities Research, 24(1).

Erkaya, O. R. (2005). Benefits of Using Short Stories in the EFL Context. Online Submission, 8.

Farrell, T. S. (2001). Teaching Reading Strategies. Reading in a Foreign Language, 13(2), 631-46.

Farstrup, A. E. (2002). What research has to say about reading instruction. TESOL Quarterly, 51(3), 215-225. 


\section{المجلة التريوية لتعليم الكبار - كلية التربية - جامعة أسبيوط}

\section{1}

Frimasary, A. E. (2015). Using short story to improve student's reading comprehension (a study at the second year student of smpn 2 kota bengkulu). Linguists: Journal of Linguistics and Language Teaching, 2(2).

Grabe, W., \& Stoller, F. L. (2011). Teaching and researching reading. Harlow. England: Pearson Education.

Harmer, J. (2007). The practice of English language teaching. Harlow: Pearson Longman,.

Harvey, S., \& Goudvis, A. (2000). Strategies that work teaching comprehension to enhance understanding. York, ME: Stenhouse Publishers.

Hismanoglu, M. (2005). Teaching English through literature. Journal of Language and Linguistic Studies, 1(1), 53-66.

Klingner, J. K., Vaughn, S., \& Boardman, A. G. (2015). Teaching reading comprehension to students with learning difficulties, 2/E. Guilford Publications.

Lindawati.(2011). Teaching Reading by using Short Stories.(Unpublished Thesis). Medan, Universitas Muhammadiyah.

Mokhtari, K., \& Reichard, C. A. (2002). Assessing students' metacognitive awareness of reading strategies. Journal of educational psychology, 94(2), 249.

National Reading Panel (US), National Institute of Child Health, \& Human Development (US). (2000). Teaching children to read: An evidence-based assessment of the scientific research literature on reading and its implications for reading instruction: Reports of the subgroups. National Institute of Child Health and Human Development, National Institutes of Health. 


\section{Improving 2nd year prep stage pupils' predicting and summarizing skills through short stories}

\section{Prof.Dr.Mohamed Abd Alwahid Ali Dr. Ahmed M. Abdul- Rahman Eman Muhammed Muhammed Ahmed}

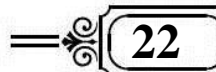

Nilsson, K. (2003). A meta search approach to locating and classifying reading material for learners of Nordic languages. Unpublished thesis, Uppsala University.

Nuttall, C. (2005). Teaching Reading Skills in a Foreign Language. Oxford, UK: Macmillan Education.

Oczkus, L. D. (2003). Reciprocal Teaching at Work: Strategies for Improving Reading Comprehension. Order Department, International Reading Association, 800 Barksdale Road, PO Box 8139, Newark, DE 197148139 (Order no. 514-553, \$23.95).

Pardede, P. (2011). Using short stories to teach language skills. JET (Journal of English Teaching), 1(1), 14-27.

Pathan, M. M. (2013). The Use of Short-stories in EFL Classroom: Advantages and Implications. Labyrinth: An International Refereed Journal of Postmodern Studies, 4(2).

Pourkalhor, O., \& Kohan, N. (2013). Teaching reading comprehension through short stories in advance classes. Asian journal of social sciences \& humanities, 2(2), 52-60.

Rabba, K. (2012). Teaching Short Stories for Tenth Grade in classroom in Palestine. Hebron University, Hebron, Palestine.(Published MA Thesis).

Rajab, H., \& Al-Sadi, A. (2015). An empirical study of reading habits and interests of Saudi university EFL learners. International Journal of Linguistics, 7(2), $1-17$. 


\section{المجلة التريوية لتعليم الكبار - كلية التربية - جامعة أسيوط}

\section{3}

Richards, J. C., Richards, J. C., \& Renandya, W. A. (Eds.). (2002). Methodology in language teaching: An anthology of current practice. Cambridge university press.

Sari, H. (2013). The Use of short Stories to develop Student's Reading comprehension Skill. Retrieved from http://hestyblogq.blogspot.com/2013/06/1

Serafini, F. (2004). Lessons in comprehension: Explicit instruction in the reading workshop. Heinemann.

Wormeli, R. (2005). Summarization in any subject: 50 techniques to improve student learning. ASCD.

Yuliana. (2013). Teaching Reading Narrative Text. (Unpublished Thesis). Medan, Universitas Medan.

Zeraatkar, F., \& Hadipanah, M. (2013). The Effects of Short Story on Junior High School EFL Learners' Reading Skill in Birjand. International Journal of Foreign Language Teaching in the Islamic World, 1(1), 1-9. 